\title{
Performance and slaughter value of Polish Merino, Booroola and Suffolk crossbred lambs*
}

\author{
W. Janiuk, A. Baranowski and J. Klewiec \\ The Institute of Animal Genetics and Breeding, \\ Polish Academy of Sciences \\ Jastrzębiec, 05-551 Mroków, Poland
}

(Received 11 September 1997; accepted 25 March 1998)

\begin{abstract}
Polish Merino lambs (ewes and rams, $\mathrm{n}=322$ ) and crossbred Polish Merino, Booroola and Suffolk lambs were raised for 8 weeks, then intensively fattened (rams, $n=66$ ) to a body weight of $35 \mathrm{~kg}$. Lambs with a genotype of $75 \%$ Merino and $25 \%$ Booroola (MBM) had lower daily weight gains (181 g; P $\leq 0.01$ ) during raising than Merino lambs (MM, $212 \mathrm{~g}$ ). This relationship was not found in lambs with a genotype of $25 \%$ Merino, $25 \%$ Booroola and $50 \%$ Suffolk (MBS, daily gain $215 \mathrm{~g}$ ). Body weight gains ( $372 \mathrm{~g}$ ) of MBS rams were larger ( $\mathrm{P} \leq 0.01)$ during fattening than those of MBM $(301 \mathrm{~g})$ and MM (309 g) rams. MBS rams utilized less ( $\mathrm{P} \leq 0.01)$ concentrate dry matter, crude protein and metabolizable energy $(2.9 \mathrm{~kg}, 608 \mathrm{~g}$ and $35.29 \mathrm{MJ})$ per $\mathrm{kg}$ body weight gain than MBM $(3.5 \mathrm{~kg}, 735 \mathrm{~g}$ and $42.63 \mathrm{MJ})$ and $\mathrm{MM}(3.5 \mathrm{~kg}, 721 \mathrm{~g}$ and $41.86 \mathrm{MJ})$ rams, respectively. The slaughter value of MBS and MM rams was similar, while that of MBM rams was inferior due to the higher fat content of the carcasses.
\end{abstract}

KEY WORDS: crossbred lambs, fattening performance, slaughter value

\section{INTRODUCTION}

The lifting of export quotas on meat-type lambs in trade with the European Union has stimulated interest in developing this area of production in Poland. However, the size of these herds in Poland is insufficient to provide an appropriate number of high commercial quality lambs for export. One of the conditions that must be met to make the lambs bred in Poland suitable for profitable meat produc-

\footnotetext{
* Supported by the State Committee for Scientific Research, Grant No S 30401507
} 
tion is improving their breeding performance and slaughter value (Krupiński, 1992). The use of rams from prolific breeds and rams from meat-type breeds for crossing with ewes of indigenous breeds for production purposes may be one of the possible methods of producing high quality meat-type lambs (Osikowski and Borys, 1989).

The objective of this study was to determine the performance and slaughter value of crossbred lambs of Polish Merino, Booroola and Suffolk breeds.

\section{MATERIAL AND METHODS}

In 1994 and 1995, Merinobooroola ewes (50\% Merino and 50\% Booroola) were mated with Suffolk or Polish Merino rams, obtaining 103 lambs with a genotype of $25 \%$ Merino, $25 \%$ Booroola and 50\% Suffolk (MBS) and 121 lambs with a genotype of $75 \%$ Merino and $25 \%$ Booroola (MBM). The control group comprised 98 Polish Merino lambs (MM, 100\% Merino). During the initial 8-week period of raising, the lambs (ewes and rams) were housed in groups with their mothers in straw lined boxes. In the first 14 days of life triplets and quadruplets were fed additionally three times daily with cow colostrum (not more than $250 \mathrm{~g}$ per head in the first week of life), then to the end of the raising period ( 56 days), with cow's milk, up to $500 \mathrm{~g}$ per head daily. From the second week of life all of the lambs were provided with constant access to standard concentrate mixture (CJ) and meadow hay. The amount of feed consumed during this period was not recorded. The lambs were weighed on days 2, 28 and 56 of life.

Fattening performance and slaughter value of lambs representing three genotypes (MBS, MBM and MM) were evaluated on rams (22 animals of each genotype) from singleton, twin and triplet births. After weaning rams were placed in individual straw-lined pens and fed individually with a granulated concentrate mixture until reaching a body weight of $35 \pm 1 \mathrm{~kg}$. The amount of feed consumed was

TABLE 1

Composition of concentrate mixture

\begin{tabular}{lc}
\hline Ingredient & $\%$ \\
\hline Ground oats & 10.00 \\
Ground barley & 47.00 \\
Soyabean oilmeal, 45\% CP & 17.00 \\
Groun field bean & 13.00 \\
Dried sugar beet pulp & 9.10 \\
Limestone, 37\% Ca & 2.73 \\
Fodder salt, 38 \% Na & 0.17 \\
Beet molassed & 1.00 \\
\hline
\end{tabular}


recorded for each ram (Table 1). In order to ensure proper rumen function, meadow hay from the first cutting was additionally provided in an amount of $100 \mathrm{~g}$ per day. The rams did not consume the entire amount. The animals were weighed weekly and feed was sampled for analysis. The basic chemical composition of feed was determined using conventional methods (Skulmowski, 1974). Neutral detergent fibre (NDF), acid detergent fibre (ADF) and acid detergent lignin (ADL) in feeds were determined according to Tecator Application Notes (Tecator, Sweden) No. 06/78, 03/78 and 04/78, respectively. Metabolizable energy content (ME) in dry matter (DM) of concentrate was calculated on the basis of the results of our own chemical analyses adapting equation no. 75 given by MAFF ( 1975):

$\mathrm{MJ} \mathrm{ME} / \mathrm{kg} \mathrm{DM}=0.012 \mathrm{X}_{1}+0.031 \mathrm{X}_{2}+0.005 \mathrm{X}_{3}+0.014 \mathrm{X}_{4}$

where $X_{1}, X_{2}, X_{3}$ and $X_{4}$ - the content $(g / k g D M)$ in feed concentrate of crude protein, ether extract, crude fibre and $\mathrm{N}$-free extractives, respectively.

The chemical composition of feeds and energy value of the concentrate are given in Table 2.

TABLE 2

Chemical composition of feeds, $\mathrm{g} / \mathrm{kg} \mathrm{DM}$

\begin{tabular}{|c|c|c|c|c|}
\hline \multirow[b]{2}{*}{ Component } & \multicolumn{2}{|c|}{ Concentrate mixture } & \multicolumn{2}{|c|}{ Meadow hay } \\
\hline & $\mathrm{g} / \mathrm{kg}$ & SD & $\mathrm{g} / \mathrm{kg}$ & $\mathrm{SD}$ \\
\hline Dry matter & 879 & 18.3 & 860 & 34.1 \\
\hline \multicolumn{5}{|l|}{ In dry matter } \\
\hline organic matter & 915 & 7.2 & 932 & 13.5 \\
\hline crude protein & 209 & 9.9 & 116 & 25.3 \\
\hline crudr fibre & 71 & 10.8 & 340 & 22.2 \\
\hline ether extract & 22 & 8.3 & 17 & 3.8 \\
\hline $\mathrm{N}$-free extractives & 613 & 21.1 & 459 & 36.9 \\
\hline NDF & 195 & 19.6 & 688 & 40.8 \\
\hline $\mathrm{ADF}$ & 96 & 9.0 & 386 & 28.4 \\
\hline ADL & 15 & 5.0 & 42 & 5.4 \\
\hline Metabolizable energy, MJ/kg DM & 12.1 & 0.14 & & \\
\hline
\end{tabular}

After completion of fattening, the rams were slaughtered and the carcasses subjected to analysis (Nawara et al., 1963). The pH (using a PH-STAR CPU, Germany) and conductivity (LF-STAR CPU, Germany) were measured in the loin and round before dissection ( $45 \mathrm{~min}$ and $24 \mathrm{~h}$ after slaughter), and $24 \mathrm{~h}$ after slaughter the colour of the loin was evaluated (OPTP-STAR CPU, Germany). After dissecting the carcass into cuts, samples were taken from mid-loin for determination of dry matter (Polish Standards, 1973), fat (Polish Standards, 1972) and crude protein (Polish Standards, 1975). 
The results were subjected to multifactorial variance analysis using the least squares method (Harvey, 1990).

Assessment of the growth of all of the lambs (ewes and rams) in the rearing period was analyzed using the model:

$$
Y i j k l=u+a i+b j+c k+d l+e i j k l
$$

Assessment of performance and slaughter value of rams was analyzed using the model:

$$
Y i j k=u+a i+b j+(a x b) i j+c k+e i j k
$$

where:

$$
\begin{aligned}
& \text { Yijk }(1) \text { - the analyzed trait } \\
& u \text { - overall average } \\
& \text { ai - effect of year }(1,2) \\
& \text { bj - effect of genotype }(1,2,3) \\
& \text { ck - effect of birth type }(1,2,3,4) \\
& \text { dl - effect of sex }(1,2) \\
& \text { (a x b)ij - interaction (year x genotype) } \\
& \text { eijk(l) - error }
\end{aligned}
$$

\section{RESULTS AND DISCUSSION}

Merinobooroola ewes bore lambs with significantly $(\mathrm{P} \leq 0.01)$ lower body weights (MBS $=3.8 \mathrm{~kg}$ and $\mathrm{MBM}=3.4 \mathrm{~kg}$ ) (Table 3) than Merino ewes (MM lambs $=4.4 \mathrm{~kg}$ ), which is in agreement with our earlier results (Klewiec and Gabryszuk, 1996). These differences were probably related to the younger age and larger litters of ewes carrying the Booroola genes than of Merino ewes (Anderson et al., 1997). In the first month of rearing, in which birth weight and the mother's milk yield have the greatest influence on a lamb's growth (Dankowski et al., 1993), the Merino lambs (MM) had the highest average daily weight gains (226 g), significantly exceeding that of MBS (207 g; P $\leq 0.05)$ and MBM (187 g; P $\leq 0.01)$ crossbreeds. In the next 4 weeks (days 29-56 of life), the MBS crossbreeds grew fastest, and their daily gains (229 g) were significantly higher than those of the MBM (184 g; $\mathrm{P} \leq 0.01)$ and Merino lambs MM $(210 \mathrm{~g} ; \mathrm{P} \leq 0.05)$. During the entire period of rearing (days $2-56$ of life) the daily gains of MBS lambs and Merino lambs were similar (215 and $212 \mathrm{~g}$, respectively) and significantly ( $\mathrm{P} \leq 0.01)$ higher than of MBM lambs $(181 \mathrm{~g})$. The MBS lambs were characterized by fast growth and at the age of 56 days did not differ in terms of body weight $(15.6 \mathrm{~kg}$ ) from Merino (MM) lambs $(16.0 \mathrm{~kg})$, whose dominance over the crossbreeds was visible at birth and at 28 days of life. Of the three compared genotypes, MBM lambs performed least 
TABLE 3

Liveweight $(\mathrm{kg})$ and daily liveweight gain $(\mathrm{g})$ of weaning lambs

\begin{tabular}{|c|c|c|c|c|c|c|c|}
\hline \multirow[b]{2}{*}{ Item } & \multirow{2}{*}{$\begin{array}{l}\text { Type } \\
\text { of } \\
\text { birth }\end{array}$} & \multicolumn{3}{|c|}{ Genotype } & \multicolumn{3}{|c|}{ Sex } \\
\hline & & $\begin{array}{c}\text { MBS } \\
n\end{array}$ & $\underset{n}{\mathrm{MBM}}$ & $\underset{n}{M M}$ & $\begin{array}{c}\text { ewes } \\
n\end{array}$ & $\begin{array}{c}\text { rams } \\
n\end{array}$ & SEM \\
\hline
\end{tabular}

Liveweight at

the age, days

$\begin{array}{rrrrrrrrrrrrrr}2 & 1 & 17 & 4.7^{\mathrm{A}} & 6 & 3.7^{\mathrm{B}} & 25 & 5.4^{\mathrm{C}} & & & & & \\ & 2 & 43 & 3.8^{\mathrm{A}} & 71 & 3.6^{\mathrm{A}} & 66 & 4.5^{\mathrm{B}} & & & & & \\ & 3 & 32 & 3.4^{\mathrm{A}} & 35 & 2.8^{\mathrm{B}} & 7 & 3.7^{\mathrm{A}} & & & & & \\ & 4 & 11 & 2.7^{2} & 9 & 2.5 & 0 & & & & & & \\ & \text { mean } & 103 & 3.8^{\mathrm{A}} & 121 & 3.4^{\mathrm{B}} & 98 & 4.4^{\mathrm{C}} & 153 & 3.5^{\mathrm{A}} & 169 & 3.8^{\mathrm{B}} & 0.07 \\ 28 & & 86 & 9.3^{\mathrm{A}} & 110 & 8.3^{\mathrm{B}} & 87 & 10.2^{\mathrm{C}} & 133 & 9.0^{\mathrm{A}} & 150 & 9.5^{\mathrm{B}} & 0.19 \\ 56 & & 85 & 15.6^{\mathrm{A}} & 105 & 13.3^{\mathrm{B}} & 82 & 16.0^{\mathrm{A}} & 127 & 14.4^{\mathrm{A}} & 145 & 15.5^{\mathrm{B}} & 0.30\end{array}$

Daily liveweight

in the period,

days

\begin{tabular}{rrlrllllllll}
$2-28$ & 82 & $207^{\mathrm{a}}$ & 104 & $187^{\mathrm{Ab}}$ & 82 & $226^{\mathrm{Bb}}$ & 125 & 202 & 143 & 212 & 5.1 \\
$29-56$ & 84 & $229^{\mathrm{Aa}}$ & 99 & $184^{\mathrm{B}}$ & 79 & $210^{\mathrm{Ab}}$ & 121 & $201^{\mathrm{b}}$ & 141 & $215^{\mathrm{a}}$ & 4.7 \\
$2-56$ & 84 & $215^{\mathrm{A}}$ & 105 & $181^{\mathrm{B}}$ & 81 & $212^{\mathrm{A}}$ & 126 & $195^{\mathrm{B}}$ & 144 & $210^{\mathrm{A}}$ & 4.0 \\
\hline
\end{tabular}

$\mathrm{a}, \mathrm{b}-\mathrm{P} \leq 0.05 ; \mathrm{A}, \mathrm{B}-\mathrm{P} \leq 0.01$

well during the rearing period. Similar relationships indicating lower viability and poorer growth during rearing of Merino lambs having Booroola genes were found by Osikowski and Borys (1996).

On the day that fattening began, MBS and MM rams had similar body weights (17.7 kg and $18.7 \mathrm{~kg}$, respectively), which were significantly ( $\mathrm{P} \leq 0.01$ ) higher than the body weight of MBM rams (15.5 kg) (Table 4). MBS and MM rams achieved slaughter weight fastest (at the age of 106 and 110 days, respectively). The fattening of MBM rams lasted 16 days longer than MBS rams $(P \leq 0.01)$ and 12 days longer than $\mathrm{MM}$ rams $\mathrm{MM}(\mathrm{P} \leq 0.05)$. During the fattening period MBS rams showed the largest daily weight gains ( $372 \mathrm{~g})$; this was significantly more $(\mathrm{P} \leq 0.01)$ than the gains of MBM $(301 \mathrm{~g})$ and MM $(309 \mathrm{~g})$ rams. Concentrate feed utilization was also best in the MBS group, where a significantly smaller amount of dry matter $(P \leq 0.01)$ was used per kg weight gain $(2.9 \mathrm{~kg}, 3.5 \mathrm{~kg}$ and $3.5 \mathrm{~kg}$, respectively), crude protein $(608 \mathrm{~g}, 735 \mathrm{~g}$ and $721 \mathrm{~g}$, respectively) and metabolizable energy (35.29 MJ, 42.63 MJ and 41.86 MJ, respectively) in comparison with MBM and MM rams. MM and MBM rams had better performance indicators than those given by Gut and Wawrzyniak (1991), and Borys and Osikowski (1996) for Merino rams and their crossbreeds with Booroola (daily gains under $300 \mathrm{~g}$; consumption of concentrate per $\mathrm{kg}$ body weight gain, from $4.6 \mathrm{~kg}$ to $4.9 \mathrm{~kg}$ ). In the 
TABLE 4

Results of rams fattening

\begin{tabular}{|c|c|c|c|c|c|c|c|}
\hline \multirow[b]{2}{*}{ Item } & \multicolumn{3}{|c|}{ Genotype } & \multicolumn{4}{|c|}{ Type of birth } \\
\hline & MBS & MBM & MM & 1 & 2 & 3 & SEM \\
\hline \multicolumn{8}{|l|}{ Age, days } \\
\hline initial & 55 & 55 & 55 & 55 & 55 & 55 & 0.3 \\
\hline final & $106^{\mathrm{A}}$ & $122^{\mathrm{Ba}}$ & 110 & 106 & $119^{\mathrm{B}}$ & 113 & 2.1 \\
\hline \multicolumn{8}{|l|}{ Liveweight, $\mathrm{kg}$} \\
\hline initial & $17.7^{\mathrm{A}}$ & $15.5^{\mathrm{B}}$ & $18.7^{\mathrm{A}}$ & $18.7^{\mathrm{A}}$ & $16.3^{\mathrm{B}}$ & 17.0 & 0.38 \\
\hline final & $35.8^{\mathrm{A}}$ & $35.0^{\mathrm{H}}$ & $35.1^{\mathrm{B}}$ & 35.4 & 35.4 & 35.1 & 0.10 \\
\hline Fattening period, days & $50^{\mathrm{A}}$ & $67^{\mathrm{Ba}}$ & $55^{\mathrm{b}}$ & $50^{4}$ & $64^{\mathrm{B}}$ & 58 & 2.1 \\
\hline Daily liveweight gain, $g$ & $372^{A}$ & $301^{\mathrm{B}}$ & $309^{\mathrm{B}}$ & $349^{-}$ & $312^{b}$ & 321 & 7.0 \\
\hline \multicolumn{8}{|l|}{ Intake/kg liveweight gain } \\
\hline dry matter, $\mathrm{kg}$ & $2.9^{\mathrm{A}}$ & $3.5^{\mathrm{B}}$ & $3.5^{\mathrm{B}}$ & $3.1^{\mathrm{A}}$ & $3.5^{\mathrm{B}}$ & 3.2 & 0.06 \\
\hline crude protein, $\mathrm{g}$ & $608^{A}$ & $735^{\mathrm{B}}$ & $721^{\mathrm{B}}$ & $653^{\mathrm{A}}$ & $738^{8}$ & 673 & 13.2 \\
\hline $\mathrm{ME}, \mathrm{MJ}$ & $35.3^{\mathrm{A}}$ & $42.6^{\mathrm{B}}$ & $41.9^{8}$ & $37.9^{\mathrm{A}}$ & $42.9^{\mathrm{B}}$ & 39.1 & 0.77 \\
\hline
\end{tabular}

$\mathrm{a}, \mathrm{b}-\mathrm{P} \leq 0.05 ; \mathrm{A}, \mathrm{B}-\mathrm{P} \leq 0.01$

case of MBS rams, performance indicators were also better than those obtained for rams from meat lines (Śliwa and Wójtowski, 1992; Gut, 1994) and confirmed the suitability of Suffolk for the production of light (liveweight under $40 \mathrm{~kg}$ ) meattype lambs (Wolf et al., 1980).

The carcass dressing percentage of MBS rams (Table 5) was similar to that of MBM rams (48.2\% and 49.1\%, respectively) and lower ( $\mathrm{P} \leq 0.05)$ than of Merino rams MM (49.5\%). The value of this trait was in the upper limits of the range (45\%-50\%) given for Merino lambs and their crossbreeds (Gut and Wawrzyniak, 1991; Borys and Osikowski, 1996) and lambs from meat lines (Gut, 1994) intensively fattened to a body weight of $35-40 \mathrm{~kg}$. Similarly as in the case of carcass dressing percentage, the share of valuable cuts in the right side of MBS rams was similar to the value obtained for MBM rams (43.2\% and $43.7 \%$, respectively) and significantly $(\mathrm{P} \leq 0.01)$ lower than in MM rams $(44.3 \%)$. Differences in the content of valuable cuts between MBS and MM rams were probably related to the greater share of neck and thin flank in MBS sides $(9.0 \%$ and $16.2 \%$, respectively) than in MM lambs ( $8.5 \%$ and $15.0 \%$, respectively) and did not have a significant effect on the tissue composition of the sides. The share of muscle and fat in the sides of MBS rams (58.4\% and $20.3 \%$, respectively) and MM rams $(59.1 \%$ and $19.6 \%$, respectively), was similar. However, in comparison with MBM rams, the sides of MBS and MM lambs contained more muscle and less fat (the differences were 
TABLE 5

Slaughter value of fattened rams

\begin{tabular}{|c|c|c|c|c|c|c|c|}
\hline \multirow[b]{2}{*}{ Item } & \multicolumn{3}{|c|}{ Genotype } & \multicolumn{4}{|c|}{ Type of birth } \\
\hline & MBS & MBM & MM & 1 & 2 & 3 & SEM \\
\hline Slaughter weight, $\mathrm{kg}$ & $33.6^{\mathrm{a}}$ & $32.9^{\mathrm{b}}$ & $32.9^{\mathrm{h}}$ & $33.5^{\mathrm{a}}$ & $33.3^{\mathrm{a}}$ & $32.7^{b}$ & 0.12 \\
\hline Cold dressing percentage & $48.2^{\mathrm{a}}$ & 49.1 & $49.5^{b}$ & 49.5 & 48.7 & 48.6 & 0.25 \\
\hline Kidney fat, $\%$ & 1.5 & $1.7^{\mathrm{a}}$ & $1.4 \mathrm{~b}$ & 1.4 & 1.4 & 1.7 & 0.05 \\
\hline Fat thickness on loin-eye, $\mathrm{mm}$ & $2.7^{\mathrm{a}}$ & $3.2^{\mathrm{Bb}}$ & $2.5^{\mathrm{A}}$ & 2.8 & 2.9 & 2.6 & 0.10 \\
\hline Loin-eye area, $\mathrm{cm} 2$ & 14.7 & $13.8^{\mathrm{a}}$ & $15.1^{\mathrm{b}}$ & 14.6 & 14.6 & 14.3 & 0.28 \\
\hline Valuable cuts, $\%$ & $43.2^{\wedge}$ & 43.7 & $44.3^{B}$ & $43.3^{\mathrm{a}}$ & 43.6 & $44.3^{b}$ & 0.15 \\
\hline \multicolumn{8}{|l|}{ In half carcass, $\%$} \\
\hline meat & $58.4^{\mathrm{a}}$ & $57.1^{\mathrm{B}}$ & $59.1^{\mathrm{A}}$ & 58.5 & 58.4 & 57.7 & 0.28 \\
\hline fat & $20.3^{a}$ & $21.9^{\mathrm{Bh}}$ & $19.6^{A}$ & 20.2 & 20.0 & 21.6 & 0.33 \\
\hline bones & 19.9 & 19.5 & 20.0 & $19.5^{\mathrm{a}}$ & $20.4^{b}$ & $19.5^{\mathrm{a}}$ & 0.18 \\
\hline \multicolumn{8}{|l|}{ In loin, $\%$} \\
\hline dry matter & $23.9^{\mathrm{A}}$ & $24.7^{\mathrm{B}}$ & 24.4 & 24.3 & 24.3 & 24.3 & 0.08 \\
\hline protein & 20.4 & 20.2 & 20.5 & 20.3 & 20.3 & 20.2 & 0.05 \\
\hline fat & $2.4^{\mathrm{A}}$ & $3.2^{\mathrm{B}}$ & 2.8 & 2.8 & 2.8 & 2.9 & 0.09 \\
\hline
\end{tabular}

$\mathrm{a}, \mathrm{b}-\mathrm{P} \leq 0.05 ; \mathrm{A}, \mathrm{B}-\mathrm{P} \leq 0.01$

significant at $\mathrm{P} \leq 0.05$ and $\mathrm{P} \leq 0.01)$. The lower $(\mathrm{P} \leq 0.05)$ content of kidney fat in MBS and MM sides in comparison with $\mathrm{MBM}(1.5,1.4$ and $1.7 \%$, respectively) also points to the lower fat content in these rams, as does the smaller ( $\mathrm{P} \leq 0.05$ and $\mathrm{P} \leq 0.01)$ fat layer around the eye of the loin $(2.7,2.5$ and $3.2 \mathrm{~mm}$, respectively) and fat content of the loin $(2.4,2.8$ and $3.2 \%$, respectively). Changes in the tissue composition of ram sides were small and clearly related to the age at slaughter: as the age increased the increase in muscle tissue slowed and fat deposition increased (Wolf et al., 1980). The muscle and fat contents of sides were satisfactory and comparable with Polish (Gut and Wawrzyniak, 1991; Borys and Osikowski, 1996) and foreign results (Wolf et al., 1980; Ellis et al., 1997) for growing meat-type lambs. Similarly as in the studies of Tański et al. (1994) no significant differences were found among genotypes in the average $\mathrm{pH}$ values, conductivity and meat color (Table 6). The $\mathrm{pH}$ of the loin and round $24 \mathrm{~h}$ after slaughter ranged from 5.60 to 5.70 , reflecting a normal rate of glycolysis, and was within the range (5.5-5.9) given by Schieffer and Scharner (1977) for high quality meat. These indicators confirmed the high slaughter value of all three genotypes of rams. However, MBS and MM rams had superior slaughter values, since the fat content of sides, an important quality parameter, was lower than in the MBM sides. 
TABLE 6

Physicochemical properties of meat

\begin{tabular}{|c|c|c|c|c|c|c|c|}
\hline \multirow[b]{2}{*}{ Item } & \multicolumn{3}{|c|}{ Genotype } & \multicolumn{4}{|c|}{ Type of birth } \\
\hline & MBS & MBM & $\mathrm{MM}$ & 1 & 2 & 3 & SEM \\
\hline \multicolumn{8}{|c|}{ Electric conductivity, $\mathrm{mS}$} \\
\hline \multicolumn{8}{|c|}{$45 \mathrm{~min}$ after slaughter } \\
\hline loin & 3.06 & 3.12 & 3.07 & 3.07 & 3.09 & 3.09 & 0.053 \\
\hline leg & 4.13 & 4.18 & 4.05 & 4.05 & 4.09 & 4.20 & 0.059 \\
\hline \multicolumn{8}{|c|}{$24 \mathrm{~h}$ after slaughter } \\
\hline loin & 2.61 & 2.46 & 2.71 & 2.48 & 2.64 & 2.66 & 0.067 \\
\hline leg & 3.42 & 3.46 & 3.70 & 3.44 & 3.49 & 3.64 & 0.094 \\
\hline \multicolumn{8}{|c|}{ Colour, \% } \\
\hline loin & 66.9 & 66.3 & 66.3 & 65.2 & 66.8 & 67.4 & 0.97 \\
\hline \multicolumn{8}{|l|}{$\mathrm{pH}$} \\
\hline \multicolumn{8}{|c|}{45 min after slaughter } \\
\hline loin & 6.65 & 6.69 & 6.68 & $6.75^{A}$ & 6.71 & $6.56^{\mathrm{B}}$ & 0.029 \\
\hline $\operatorname{leg}$ & 6.53 & 6.44 & 6.56 & 6.51 & 6.51 & 6.48 & 0.033 \\
\hline \multicolumn{8}{|c|}{$24 \mathrm{~h}$ after slaughter } \\
\hline loin & 5.66 & 5.70 & 5.64 & 5.65 & 5.66 & 5.69 & 0.024 \\
\hline leg & 5.61 & 5.64 & 5.63 & $5.66^{A}$ & $5.61^{\mathrm{B}}$ & 5.60 & 0.012 \\
\hline
\end{tabular}

$\mathrm{a}, \mathrm{b}-\mathrm{P} \leq 0.05$

\section{CONCLUSIONS}

The results of this experiment indicate that the lambs borne by Merinobooroola ewes weighed less at birth than those from Merino ewes. The $25 \%$ share of the Booroola genotype in the MBM lambs caused a significantly lower increase in body weight (up to $15 \%$ ) during the period of rearing (from days 2 to 56 ) in comparison with the gains of Merino lambs, MM. These unfavourable effects of Booroola genes were offset by the $50 \%$ share of Suffolk genes in MBS lambs. During intensive fattening MBS rams had greater daily body weight gains in comparison with MBM and Merino rams (by 19 and $17 \%$, respectively). MBS rams also utilized feed most efficiently, using about $16.5 \%$ crude protein and metabolizable energy less than the other rams. The slaughter value of MBS rams was similar to that of MM rams, and better than that of MBM lambs, in which a greater fat contents of sides was found. 


\section{REFERENCES}

Anderson J.M.L., Boyd J.S., Waterhouse A., 1997. The effect of litter size, age of ewe and Booroola gene (Fec B) on the birth and placental characteristics of Texel ewes. Proceedings of British Society of Animal Sciences, Annual Meeting, Sacarborough, p. 179

Borys B., Osikowski M., 1996. Two-stage commercial crossing of Polish Merino sheep with prolific Booroola and Romanov rams. II. Fattening performance, slaughter value and skin quality in first- and second-stage crosses. Anim. Sci. Pap. Rep. 14 (1), 45-58

Dankowski A., Bemacka H., Matylewska K., Włodarczak M., 1993. Some problems on the lambs breeding at their early weaning (in Polish). Zesz. Nauk. ATR Bydgoszcz, 185, Zoot. 24, 31-38

Ellis M., Webster G.M., Merrell B.G., Brown I., 1997. The influence of terminal sire breed on carcass composition and eating quality of crossbred lambs. Anim. Sci. 64, 77-86

Gut A., Wawrzyniak M., 1991. Meat value of male lambs from 3 synthetic lines, Polish Merino and their crosses (in Polish). Prz. hod., Zesz. Nauk. No. 4, „Sheep menagement and breeding”, 237-244

Gut A., 1994. Formation of Whiteheaded multon sheep - a synthetic sire line (in Polish). Rocz. Nauk. AR Poznań. Rozpr. Nauk. No. 249

Harvey W.R., 1990. Mixed Model Least-Squares and Maximum Likelihood Computer Program PC-2. Ohio State University

Klewiec J., Gabryszuk M., 1996. The effect of different share of Merino sheep in the genotype of Merino x Booroola crossbreds (in Polish). Prace Mat. Zoot. 48, 7-16

Krupiński J., 1992. Current problems of Polish sheep breeding and the prospects for its development (in Polish). Biul. inf. Inst. Zoot. 30 (1-2) 3-16

MAFF, 1975. Energy Allowances and Feeding System for Ruminants. London, Techn. Bull. No 33

Nawara W., Osikowski M., Kluz I., Modelska M., 1963. Results of ram evaluation based on progeny testing conducted in 1962 at the Institute of Animal Production Stations (in Polish). Inst. Zoot. Press, No. 166. PWRiL, Warszawa

Osikowski M., Borys B., 1989. Intensification and improvement in effectiveness of slaughter lambs production (in Polish). Biul. inf. Inst. Zoot. 27 (3-4), 60-84

Osikowski M., Borys B., 1996. Two-stage commercial crossing of Polish Merino sheep with prolific Booroola and Romanov rams. I. Performance of Fl ewes. Anim. Sci. Pap. Rep. 14 (1), 33-44

Polish Standard, 1972. Meat and meat products. Determination of fat content (in Polish). PN-73/A82111

Polish Standard, 1973. Meat and meat products. Determination of moisture content (in Polish). PN$73 /$ A- 82110

Polish Standard, 1975. Agricultural food products. Determination of nitrogen by the Kjeldahl method and expressing as protein. PN-75/A-04018

Schieffer G., Scharner E., 1977. Einfluss von Alter, Lebendmasse, Geschlecht und Geburtstyp auf ausgewählte Qualitätsparameter von Mastlammfleisch. Arch. Tierzucht 20, 129-36

Skulmowski J., 1974. Methods of Determination the Composition and Feeds Quality (in Polish). PWRiL, Warszawa

Śliwa Z., Wójtowski J., 1992. Meat value of sheep of synthetic prolific-meat line (in Polish). PTPN, Pr. Kom. Nauk Rol. Leś. LXXIII, 109-115

Tański Z., Brzostowski H., Milewski S., Stempel R., 1994. The influence of the slaughter age of ram lambs of the Polish Merino breed and its crossbreds on some meat quality indices (in Polish). Prz. hod., Zesz. Nauk. No. 13 „Sheep management and breeding”, 251-258

Wolf B.T., Smith C., Sales D.I., 1980. Growth and carcass composition in the crossbred progeny of six terminal sire breeds of sheep. Anim. Prod. 31, 307-313 


\section{STRESZCZENIE}

Wyniki produkcyjne i wartość rzeźna jagniąt mieszańców z udzialem krwi merynosa polskiego, boorooli i suffolka

Jagnięta-mieszańce z udziakem w genotypie $25 \%$ merynosa polskiego, $25 \%$ boorooli i $50 \%$ suffolka (MBS), mieszańce z udziałem 75\% merynosa polskiego i $25 \%$ boorooli (MBM) oraz jagnięta merynosa polskiego (MM, grupa kontrolna) odłączano od matek w wieku $56 \mathrm{dni}$, a następnie tryczki intensywnie tuczono do masy ciała $35 \mathrm{~kg}$, ubijano i poddawano analizie rzeźnej. W okresie odchowu (od urodzenia do 56 dnia życia) stwierdzono istotnie $(\mathrm{P} \leq 0,01)$ gorsze dzienne przyrosty jagniąt MBM (181 g) niż jagniąt MBS (215 g) i jagniąt merynosowych MM (212 g). W okresie tuczu przyrosty dzienne tryczków MBS były istotnie $(\mathrm{P} \leq 0,01)$ większe $(372 \mathrm{~g})$ niż tryczków MBM $(301 \mathrm{~g})$ i tryczków MM ( $309 \mathrm{~g})$. Podobne zależności między genotypami stwierdzono w wykorzystaniu suchej masy paszy, białka ogólnego i energii metabolicznej na $1 \mathrm{~kg}$ przyrostu masy ciała (MBS odpowiednio 2,9 kg, $608 \mathrm{~g}$ i 35,29 MJ; MBM odpowiednio 3,5 kg, 735 g i 42,63 MJ; MM odpowiednio 3,5 kg, $721 \mathrm{~g} \mathrm{i} \mathrm{41,86} \mathrm{MJ)} \mathrm{Wyniki} \mathrm{oceny} \mathrm{poubojowej} \mathrm{potwierdziły} \mathrm{dobrą} \mathrm{wartość} \mathrm{rzeź-}$ ną tryczków wszystkich trzech genotypów, lepszą wartością rzeźną charakteryzowały się tryczki MBS i MM, których otluszczenie tuszy było mniejsze niż tryczków MBM. 